\title{
DAUN AFRIKA (Vernonia amygdalina) SEBAGAI ALTERNATIF ANTIBIOTIK INFEKSI NOSOKOMIAL YANG DISEBABKAN OLEH Pseudomonas aeruginosa
}

\author{
Ghaaliya Dyah Adheline ${ }^{1}$
}

${ }^{1}$ Fakultas Kedokteran, Universitas Lampung

\begin{abstract}
Bitter Leaf (Vernonia amygdalina) as an Alternative Antibiotic Nosocomial Infections Caused by Pseudomonas aeruginosa. Nosocomial infection currently is the one cause of increased morbidity and mortality in hospitals. Many nosocomial infections are caused by the Pseudomonas aeruginosa bacteria. Administration of antibiotics is a therapeutic choice in curing infections caused by $P$. aeruginosa. However, if the administration of antibiotics not given rationally it can cause resistance. Therefore alternative medicine using herbal plants is widely used at this time. Bitter Leaf (Vernonia amygdalina) have been known by the people of Southern Nigeria as traditional medicine that can be used for various diseases, including infectious diseases. Bitter leaf ( $V$. amygdalina) have been carried out by many clinicians which have the potential as antibiotics. These studies say that bitter leaf extract effectively shows good activity against many types of bacteria, it can be gram-negative or gram-positive bacteria. Components in African leaves that has been believed have responsibility for potential antibacterial effect are flavonoids, tannins, saponins and alkaloids.
\end{abstract}

Keywords : antibacterial, bitter leaf, Pseudomonas aeruginosa

\begin{abstract}
Abstrak : Daun Afrika (Vernonia amygdalina) sebagai Alternatif Antibiotik Infeksi Nosokomial yang Disebabkan oleh Pseudomonas aeruginosa. Infeksi nosokomial saat ini merupakan salah satu penyebab meningkatnya angka kesakitan (morbiditas) dan angka kematian (mortalitas) di rumah sakit. Infeksi nosokomial banyak disebabkan oleh bakteri Pseudomonas aeruginosa. Pemberian antibiotik menjadi salah satu terapi dalam menyembuhkan infeksi yang disebabkan oleh $P$. aeruginosa. Namun, apabila pemberian antibiotik tidak dilakukan secara rasional dapat menimbulkan resistensi. Oleh karena itu pengobatan alternatif dengan menggunakan tanaman herbal banyak digunakan pada saat ini. Daun afrika (Vernonia amygdalina) telah dikenal oleh masyarakat Nigeria Selatan sebagai obat tradisional yang dapat digunakan untuk berbagai macam penyakit, termasuk penyakit infeksi. Daun afrika ( $V$. amygdalina) telah banyak dilakukan penelitian oleh para klinisi dan memiliki potensi sebagai antibiotik. Penelitian - penelitian tersebut menyatakan bahwa ekstrak daun afrika ( $V$. amygdalina) dengan efektif menunjukkan aktivitas yang baik terhadap banyak jenis bakteri, baik itu bakteri gram negatif ataupun gram positif. Komponen dalam daun afrika yang diyakini bertanggung jawab atas potensi antibakteri adalah flavonoid, tannin, saponin and alkaloid.
\end{abstract}

Kata kunci: antibakteri, daun afrika, Pseudomonas aeruginosa

PENDAHULUAN

Pseudomonas aeruginosa ( $P$. aeruginosa) merupakan bakteri penyebab infeksi yang sering terjadi di lingkungan rumah sakit (nosokomial) dengan angka kejadian di dunia sebesar 10 - 15\% (Strateva dan Yordanov, 2009). Pseudomonas aeruginosa menyebabkan infeksi saluran kemih di rumah sakit sebesar 7 - $10 \%$ dan Sekitar 10 - $20 \%$ infeksi $P$. Aeruginosa terjadi pada pasien septikemia di unit perawatan intensif (ICU), sistik fibrosis, luka bakar, dan infeksi luka (Biswal dkk., 2014).
Pseudomonas

aeruginosa

menyebabkan infeksi terutama pada pasien dengan penurunan sistem imun (Jawetz dkk., 2017). Infeksi terjadi pada pasien yang telah dirawat di rumah sakit lebih dari satu minggu. Pseudomonas aeruginosa memiliki Infeksi yang rumit serta dapat mengancam jiwa. Pseudomonas aeruginosa dapat menyebabkan penyakit pneumonia, bakteremia, endokarditis, meningitis, abses otak, otitis eksterna, otitis media, keratitis bakterial, endoftalmitis, osteomielitis, diare, enteritis, enterokolitis, infeksi saluran kemih 
(ISK), ecthyma gangrenosum dan lain lain (Friedrich dkk., 2017).

Pengobatan infeksi $P$. Aeruginosa menggunakan penisilin antipseudomonas yaitu piperasilin yang dikombinasi bersama tobramisin yang merupakan suatu aminoglikosida (Jawetz dkk., 2017). Obat lain yang aktif terhadap $P$. Aeruginosa meliputi aztreonam, karbapanem dan kuinolon terbaru termasuk siprofloksasin (Bassetti dkk., 2018).

Infeksi $P$. aeruginosa sulit untuk diobati karena bakteri tersebut resisten terhadap sebagian besar antibiotik. Resistensi disebabkan oleh adanya biofilm yang dimiliki bakteri tersebut (Sanjaya dkk., 2019). Multidrug resistant Pseudomonas aeruginosa (MDR-PA) adalah bakteri $P$. aeruginosa yang resisten terhadap tiga atau lebih golongan antibiotik pilihan untuk bakteri ini. Kasus MDRPA yang di laporkan bervasiasi dari $0,6 \%-32 \%$ menurut berbagai penelitian yang dilakukan di lokasi geografis yang berbeda. Prevalensi MDRPA yang meningkat selama dekade terakhir pada pasien rawat inap rumah sakit menyebabkan sedikitnya pilihan untuk terapinya (Kalaivani dkk., 2013).

Daun afrika (Vernonia amygdalina) telah dikenal oleh masyarakat Nigeria Selatan sebagai obat tradisional (Okeke dkk., 2015). Bioaktivitas $V$. amygdalina dapat berguna sebagai antibakteri, antifungi, antidiabetik, antiplasmodial, antikarsinogenik, dan lain - lain. Komponen dalam daun afrika yang dipercaya bertanggung jawab atas potensi antibakteri adalah flavonoid, tannin, saponin and alkaloid (Paul dkk., 2018).

\section{METODE}

Tulisan ini dibuat menggunakan metode pengumpulan data sekunder yang sudah tertera pada sitasi dan daftar pustaka.

\section{HASIL DAN PEMBAHASAN}

Pseudomonas

aeruginosa

merupakan bakteri obligat aerob, berbentuk batang, bersifat gram negatif dan motil yang berukuran sekitar 0,6 $\times$ $2 \mu \mathrm{m}$. Bakteri ini menjadi patogen jika mencapai daerah yang luka, saat penggunaan kateter urin, pemakaian infus, atau jika terdapat neutropenia. Bakteri melekat pada membran mukosa, mengivasi secara lokal dan menyebabkan penyakit sistemik. Lipopolisakarida pada bakteri $P$. aeruginosa bertanggung jawab langsung atas demam, syok, oligouria, leukositosis maupun leukopenia, koagulasi intravaskular diseminata dan sindrom gawat napas pada pasien yang terinfeksi bakteri ini (Jawetz dkk.,2017). Pseudomonas aeruginosa menyebabkan infeksi pada luka dan luka bakar yang menimbulkan pus hijau kebiruan, jika bakteri masuk melalui pungsi lumbal menyebabkan meningitis dan jika masuk melalui kateter menyebabkan ISK. Jika masuk melalui alat bantu napas menyebabkan pneumonia nekrotikans dan dapat menyebabkan infeksi pada mata setelah prosedur pembedahan. Pseudomonas aeruginosa dapat menyebabkan sepsis yang fatal jika mengivasi aliran darah, otitis eksterna dan kelamahan umum. Jika terjadi sepsis pada infeksi $P$. aeruginosa akan timbul nekrosis hemoragik pada kulit yang dikenal sebagai ektima gangrenosum yang sering di akibatkan oleh bakteri ini dibandingkan oleh organisme lain (Jawetz dkk.,2017).

Pengobatan infeksi $P$. aeruginosa biasanya menggunakan 8 katagori antibiotik yaitu aminoglikosida (gentamisin, tobramisin, amikasin, netilmisin), karbapenem (imipenem, meropenem), sefalosporin (ceftazidime, cefepime), fluoroquinolon (siprofloksasin, levofloksasin), penisillin dengan $\beta$-lactamase inhibitors (BLI) (tikarsillin and piperasilin yang dikombinasikan dengan asam klavulanat atau tazobaktam), monobactam (aztreonam), fosfomisin and polimiksin (kolistin, polimiksin B) (Zowalaty dkk., 2015).

Pseudomonas aruginosa resisten terhadap banyak obat antimikroba sehingga bakteri ini menjadi dominan dan penting (Jawetz dkk.,2017). Berbagai mekanisme terlibat dalam resistansi obat yang terjadi pada $P$. aeruginosa. Pada resistansi bawaan melibatkan pompa eflux yang 
diekspresikan secara berlebihan dan permeabilitas membran luarnya yang rendah. Sedangkan pada resistensi yang diperoleh melibatkan akuisisi gen resistan atau mutasi pada gen yang mengkode porin, pompa efflux, protein pengikat penisilin, dan kromosomal blaktamase. Semua mekanisme tersebut berkontribusi terhadap resistensi terhadap b-laktam, karbapenem, aminoglikosida, dan fluoroquinolon (Bassetti dkk., 2018; Pachori dkk., 2019).

Menurut penelitian oleh Kalaivani dkk pada tahun 2013, Isolat MDRPA menunjukkan resistensi tingkat tinggi terhadap siprofloksasin (95\%), tobramisin (92\%), seftriakson dan gentamisin, $(83 \%)$. Empat puluh empat isolat $(59 \%)$ menunjukkan resistansi terhadap amikasin dan resistansi $51 \%$ diketahui untuk kombinasi piperasilin / tazobaktam. Di antara karbapenem, imipenem dan resistansi diamati masingmasing $36 \%$ dan 53\%. Tak satu pun dari isolat yang resisten terhadap polimiksin B. Di antara 75 isolat MDRPA, 13 isolat, yang diisolasi dari sampel urin, menunjukkan $77 \%$ resistensi terhadap norfloxacin dan karbenisilin (Kalaivani dkk., 2013).

Pada penelitian dua tahun berikutnya oleh Hassuna dkk hasil uji 50 strain $P$. aeruginosa terhadap 12 agen antimikroba menunjukkan sangat resisten terhadap isolat Ceftazidime (CAZ) 43 (86\%). Resistensi yang lebih tinggi juga dicatat untuk Cefotaksim (CTX): 36 isolat (72\%) dan Cefepime (FEP): 21 isolat (42\%), Ampisilin (AM): 21 isolat $(42 \%)$, Ofloksasin (OFX): 17 isolat (34\%). Di sisi lain, ada resistensi yang relatif rendah terhadap isolat Kloramfenikol (C) 23 ; $(46 \%)$, isolat Ampisilin/Sulbaktam (SAM) 16; (32\%), isolat Gentamycin (CN) 9; $(18 \%)$, isolat Streptomisin (S) 7; (14\%) (Hassuna dkk., 2015).

Meningkatnya angka resistensi antibiotik merupakan salah satu penghambat utama dalam tercapainya hasil pengobatan yang sukses dan pengontrolan terhadap patogenisitas mikroba. Karena kemungkinan beberapa resistensi dan efek samping dari antimikroba sintetis, peningkatan perhatian telah diarahkan pada antimikroba alami berbahan dasar tumbuhan. Salah satu tumbuhan yang telah lama dipercaya memiliki aktivitas antibakteri yang cukup baik terhadap berbagai macam bakteri ialah daun afrika (Vernonia amygdalina) (Jiang dkk., 2011).

Pemeriksaan secara in vitro pada V. amygdalina menunjukkan adanya aktivitas antimikroba terhadap bakteri Gram-positif dan Gram-negatif, termasuk spesies Staphylococcus, Proteus, Escherichia, Pseudomonas, Streptococcus, Klebsiella, dan Salmonella (Yar'adua dkk., 2015). Aktivitas antibakteri in vitro dari ekstrak esensial yang diperoleh dari daun tanaman daun afrika yang di ekstrak menunjukkan aktivitas antimikroba yang baik terhadap Escherichia coli, Pseudomonas aeruginosa dan Staphylococcus aureus (Udochukwu dkk., 2015).

Komponen dalam daun afrika yang dipercaya bertanggung jawab atas potensi antibakteri adalah flavonoid, tannin, saponin and alkaloid (Paul dkk., 2018). Aktivitas antibakteri senyawa flavonoid pada daun afrika bekerja dengan cara mendenaturasi protein, mengganggu permukaan dan kebocoran sel bakteri. Flavonoid merupakan turunan senyawa fenol yang dapat berinteraksi dengan sel bakteri dengan cara absorbsi yang dalam prosesnya melibatkan ikatan hidrogen. Fenol membentuk kompleks protein dengan ikatan lemah. Ikatan tersebut akan segera terurai dan diikuti oleh penetrasi fenol ke dalam sel, dan menyebabkan presipitasi dan denaturasi protein. Selain itu fenol dapat menghambat aktivitas enzim bakteri yang akan mengganggu metabolisme bakteri tersebut (Gulfraz dkk., 2014).

Aktivitas antimikroba tannin ditunjukkan dengan mekanisme deprivasi substrat yang dibutuhkan untuk pertumbuhan mikroba, penghambatan enzim ekstraseluler mikroba, penghambatan fosforilasi oksidatif, pembentukan kompleks ion logam dengan membran sel bakteri yang menyebabkan perubahan morfologi dinding sel dan meningkatkan permeabilitas membran mikroba. Bakteri patogen seperti E. coli, Salmonella, 
Shigella, Staphylococcus, Pseudomonas dan Helicobacter pylori sensitif terhadap tanin (Huang dkk., 2018).

Mekanisme saponin sebagai antibakteri adalah mengurangi tegangan permukaan dengan membentuk kompleks dengan membran sel melalui ikatan hidrogen, sehingga meningkatkan permeabilitas dan menyebabkan senyawa intraseluler keluar dari sel. Saponin berdifusi melalui membran luar dan dinding sel, kemudian mengikat ke membran sitoplasma dan mengurangi stabilitas dan menyebabkan sitoplasma bocor keluar dari sel yang menyebabkan kematian sel (Ngajowa dkk., 2013). Cara kerja antibakteri dari alkaloid memiliki mekanisme yang berbeda dari setiap kelasnya. Alkaloid kelas intheindolizidine bekerja dengan menghambat sintesis asam nukleat dengan menghambat enzim dihydrofolate reduktase. Alkaloid kelas isoquinoline bertindak dengan mengganggu cincin- $Z$ dan menghambat pembelahan sel (Cushnie dkk., 2014).

$\mathrm{Uji}$ in vitro yang menarik tentang aktivitas antibakteri $V$. amygdalina terhadap $P$. aeruginosa dilakukan di Nigeria, di mana ekstrak $V$. amygdalina dinyatakan sebagai metode difusi cakram dan dibandingkan dengan antibiotik standar. Aktivitas antibakteri dari tiga ekstrak daun $V$. amygdalina menunjukkan bahwa ekstrak etanol lebih efektif, memiliki zona penghambatan diameter rata-rata berkisar antara 9,0 $\mathrm{mm}$ hingga 24,0 pada konsentrasi yang berbeda antara 6,25 mg - $50 \mathrm{mg}$. Ekstrak metanol menunjukkan tingkat aktivitas yang signifikan dengan zona penghambatan diameter rata-rata berkisar antara 10,0 mm - 17,0 mm. Ekstrak air daun $V$. amygdalina menunjukkan aktivitas antibakteri terhadap isolat dengan zona penghambatan diameter rata-rata antara 9,0 mm - 13,5 mm (Paul dkk., 2018).

Penelitian ditahun yang sama juga dilakukan oleh Evbuomwan dkk pada tahun 2018, Aktivitas antibakteri dari $V$. amygdalina terhadap bakteri $P$. aeruginosa ditemukan bergantung pada sifat pelarut yang digunakan ekstraksi dan konsentrasi ekstrak. Ekstrak etanol diamati memiliki lebih banyak aktivitas antibakteri dibandingkan dengan ekstrak air. Ini disebabkan oleh fakta bahwa daun yang diekstraksi dengan etanol lebih banyak komponen bioaktif pada tanaman dibandingkan dengan air. Zona penghambatan diproduksi oleh ekstrak etanol berkisar antara 11,0 \pm $1.0 \mathrm{~mm}$ pada $50 \mathrm{mg} / \mathrm{ml}$ sampai $16.0 \pm$ $5.0 \mathrm{~mm}$ pada $200 \mathrm{mg} / \mathrm{ml}$. Zona hambat dalam ekstrak air berkisar antara 8,0 \pm $2,0 \mathrm{~mm}$ pada $25 \mathrm{mg} / \mathrm{ml}$ sampai $12,5 \pm$ 1,5 pada $200 \mathrm{mg} / \mathrm{ml}$. Konsentrasi hambat minimum baik dari ekstrak etanol maupun ekstrak air terhadap $P$. aeruginosa adalah 50mg / ml (Evbuomwan dkk., 2018).

\section{KESIMPULAN}

\section{Pseudomonas}

aeruginosa

merupakan bakteri penyebab terbanyak infeksi nasokomial dan perlu ditatalaksana dengan mengkonsumsi antibiotik. Penggunaan antibiotik yang tidak rasional dan resistensi bawaan Pseudomonas aeruginosa menimbulkan dampak berupa timbulnya resistensi terhadap sebagian besar antibiotik. sehingga telah dilakukan beberapa penelitian yang bertujuan untuk mencari obat alternatif pengganti antibiotik dari bahan alami seperti tanaman. Salah satu tanaman yang memiliki efek antibiotik adalah daun afrika (Vernonia amygdalina)

\section{DAFTAR PUSTAKA}

Bassetti M, Vena A, Croxatto A, Righi E, Guery B. (2018). How to manage Pseudomonas aeruginosa infections. Drugs Context. 7:212527

Biswal I, Arora BS, Kasana D, Neetushree. (2014). Incidence of multidrug resistant pseudomonas aeruginosa isolated from burn patients and environment of teaching institution. J Clin Diagn Res.8(5):DC26-29.

Cushnie T, Cushnie B, Lamb A. (2014). Alkaloids: An overview of their antibacterial, antibiotic-enhancing and antivirulence activities. Int $\mathrm{J}$ Antimicrob Agents.44: 377-86.

Evbuomwan L, Chukwuka EP, Obazenu EI, Ilevbare L. (2018). Antibacterial activity of Vernonia 
amygdalina leaf extracts against multidrug resistant bacterial isolates. J Appl Sci Environ Manage. 22(1):17-21.

Friedrich M, Cunha BA, Lessnau KD, Lazo KGG. (2017). Pseudomonas aeruginosa Infections. Medscape [Online Journal] [diunduh 26 Oktober 2019]. Tersedia dari: https://emedicine.medscape.com/a rticle/226748-overview.

Gulfraz M, Imran M, Khadam S. (2014). A comparative study of antimicrobial and antioxidant activities of garlic (Allium sativum L.) extracts in various localities in Pakistan. Afr J Plant Sci.8:298306.

Hassuna NA, Mohamed AHI, AboEleuoon SM, Rizk HAWA. (2015). High prevalence of multidrug resistant Pseudomonas aeruginosa recovered from infected burn wounds in children. iMedPub. 6(4): 1.

Huang $Q$, Liu $X$, Zhao $G$, Tianming $H$, Wang Y. (2018). Potential and challenges of tannins as an alternative to in-feed antibiotics for farm animal production. J Anim Physiol An N.4(2):137-50.

Jawetz, Melnick, Adelberg. (2017). Mikrobiologi kedokteran. Edisi ke27. Jakarta: Penerbit Buku Kedokteran EGC.

Jiang Y, Wua N, Fua Y-J, Wanga W, Luoa M, Zhaoa C-J, Dkk. (2011). Chemical composition and antimicrobial activity of the essential oil of rosemary. Elsevier. 32(1):63-8.

Kalaivani R, Shashikala P, Devi CS, Prashanth KK, Saranathan R. (2013). Phenotypic assays for detection of esbl and $\mathrm{mbl}$ producers among the clinical isolates of multidrug resistant Pseudomonas aeruginosa from a tertiary care hospital. IJCRR.5(17).

Ngajowa M, Abidjulua J, Kamua VS. (2013). Pengaruh Antibakteri Ekstrak Kulit Batang Matoa (Pometia pinnata) terhadap Bakteri Staphylococcus aureus secara In vitro. Jurnal Mipa Unsrat Online.2(2):128-32.
Okeke CU, Ezeabara CA, Okoronkwo OF, Udechukwu CD, Uka CJ, Bibian O Aziagba. (2015). Determination of nutritional and phytochemical compositions of two variants of bitter leaf (Vernonia amygdalina Del). J Hum Nutr Food Sci.3(3): 1065 .

Pachori P, Gothalwal R, Gandhi P. (2019). Emergence of antibiotic resistance Pseudomonas aeruginosa in intensive care unit: A critical review. Genes Dis.6(2):109-19.

Paul TA, Taibat I, Kenneth EI, Haruna NI, Baba OV, Helma AR. (2018). Phytochemical and antibacterial analysis of aqueous and alcoholic extracts of Vernonia amygdalina (del.) leaf. World J Pharm.7(7):917.

Sanjaya IGANAP, Fatmawati NND, Hendrayana MA. (2019). Prevalensi isolat klinis Pseudomonas aeruginosa yang memiliki gen lasI dan las $R$ di rumah sakit umum pusat Sanglah Denpasar tahun 2013 - 2016. e-jurnal medika udayana.8(6).

Strateva TV, Yordanov D. (2009). Pseudomonas aeruginosa - a phenomenon of bacterial resistance. J. Med. Microbiol.58(9):1133-48.

Udochukwu U, Omeje FI, Uloma IS, Oseiwe FD. (2015). Phytochemical analysis of Vernonia amygdalina and Ocimum gratissimum extracts and their antibacterial activity on some drug resistant bacteria. Am J Res.3(5).

Yar'adua AI, Shuaibu L, Nasir A. (2015). Phytochemical and Antibacterial Investigation of Leaf Extracts of Vernonia amygdalina. Br Microbiol Res J.10(1):1-6.

Zowalaty MEE, Thani AAA, Webster TJ, Zowalaty AEE, Schweizer HP, Nasrallah GK, Dkk. (2015). Pseudomonas aeruginosa: Arsenal of resistance mechanisms, decades of changing resistance profiles, and future antimicrobial therapies. Future Microbiol.10(10):16831706. 